\title{
KELUARGA SAKINAH DALAM KAJIAN HUKUM ISLAM
}

\author{
Asman \\ Institut Agama Islam Sultan Muhammad Syafiuddin Sambas \\ raja.asman86@gmail.com
}

\begin{abstract}
Households in this modern era experience many challenges and problems, so that many households in their journey end up in a messy household. Husbands or wives and even children no longer feel comfortable in the house, so each of them looks for pleasure and an antidote for the anxiety he faces. From this background, the writer wants to explain scientifically about the sakinah family in the study of Islamic law. The method used in conjunction with this research is the Research library (literature) by taking sources from books, journals and other literature that support this research. The findings of this study explain that in theory the Sakinah family is different from its practice in society. The conclusion of this research is to adapt the theory and practice, the application of the sakinah family can be grouped into three groups: First, to obey religious advice, Second, to create a sakinah family, Third, to develop Islamic da'wah.
\end{abstract}

Keywords: Sakinah Family, Islamic Law

\begin{abstract}
Abstrak
Rumah tangga dalam era modern ini mengalami banyak tantangan dan problema, sehingga tidak sedikit rumah tangga dalam perjalanannya berujung pada sebuah rumah tangga yang berantakan. Suami atau isteri bahkan anak tidak lagi merasa nyaman untuk berada dalam rumah, sehingga masingmasing mencari kesenangan dan penawar atas kegelisahan yang dihadapinya. Dari lata belakang tersebut penulis ingin memaparkan secara ilmiah tentang keluarga sakinah dalam kajian hukum Islam. Metode yang di gunakan padan penelitian ini adalah library Research (kepustakaan) dengan mengambil sumber dari buku, jurnal dan literatur lainya yang mendukung dalam penelitian ini. Temuan dari penelitian ini menjelaskan bahwa secara teori tentang keluarga sakinah berbeda dengan praktinya dimasyarakat. Kesimpulan dari penelitian ini adalah untuk menyesuiakan teori dan prktik adalah aplikasi keluarga sakinah itu dapat dikelompokkan menjadi tiga: Pertama, untuk menaati anjuran agama, Kedua, untuk mewujudkan keluarga sakinah, Ketiga, untuk mengembangkan dakwah islamiyah.
\end{abstract}

Kata Kunci: Keluarga Sakinah, Hukum Islam 


\section{Pendahuluan}

Sering orang berkata bahwa membina rumah tangga bukanlah persoalan yang mudah. Terkadang rumah tangga yang diharapkan dapat menciptakan kebahagiaan justru berbalik malah menciptakan malapetaka. Kenyataan ini bukanlah hisapan jempol belaka, karena banyak sekali dapat kita jumpai hancurnya satu keluarga yang diakibatkan oleh satu dan banyak sebab. Sehingga banyak orang yang beranggapan bahwa hidup sendiri lebih baik atau menjalin hubungan tidaklah perlu ikatan (pernikahan) supaya terbebas dari jeratan komitmen, dan lain-lain.

Paradigma seperti di atas tentunya salah besar. Islam tidak pernah mengajarkan untuk membenci pernikahan, apalagi memilih untuk hidup sebatang kara atau bahkan bebas bersama-sama tanpa adanya ikatan. Islam justru menganjurkan bagi umatnya untuk membina rumah tangga. Adapun persoalan yang timbul itu semata-mata diakibatkan oleh kita sendiri yang tidak memahami arti pernikahan dengan sesungguhnya. ${ }^{1}$ Rumah tangga tanpa cinta akan berlangsung hanya dalam sekejap mata, sementara rumah tangga yang dilandasi cinta akan senantiasa abadi sepanjang zaman.

Menurut undang-undang perkawinan nomor 1 tahun 1974 pengertian dan tujuan perkawinan terdapat dalam satu pasal, yaitu bab 1 pasal 1 menetapkan bahwa "perkawinan adalah ikatan lahir batin antara seorang pria dengan seorang wanita sebagai suami istri dengan tujuan membentuk rumah tangga, keluarga yang bahagia dan kekal berdasarkan Ketuhanan Yang Maha Esa". Dengan demikian jelas bahwa diantara tujuan pernikahan adalah membentuk sebuah rumah tangga yang sakinah, mawaddah dan warahmah. ${ }^{2}$

Cinta dan rumah tangga merupakan salah satu kebutuhan psikis, yang bersifat primer atau pokok bagi semua orang. Karena semua orang pasti sangat mendambakan cinta dan hidup berumah tangga, seperti ketika merasa lapar dan membutuhkan makan. Hidup tanpa cinta sudah tentu sangat sulit, terasa kering dan membosankan, hampa akan kebahagiaan dan keceriaan, kurang menggairahkan, sunyi akan keinginan dan harapan.

Orang yang paling beruntung adalah siapa saja yang menemukan seorang kekasih yang pantas dinikahi atau menikah dengan seseorang yang dicintai. Hidup tanpa rumah tangga serasa menu yang hambar, tanpa rasa. Oleh karena itu, orang yang tidak berumah tangga sering kali merasa ada kekurangan dalam dirinya dan hidupnya seakan kosong, walaupun ia dikelilingi oleh banyak sahabat dan rekan-rekan, baik laki-laki maupun perempuan. ${ }^{3}$

\footnotetext{
1 M. Sayyid Ahmad Al-Masayyar, Fiqih Cinta Kasih, Rahasia Kebahagiaan Rumah Tangga, (Jakarta, Airlangga, 2008),10.

2 Amirah Mawarid, Pendidikan Pra Nikah; Ikhtiar Membentuk Keluarga Sakinah. Jurnal Tarbawi. Vol. 2. No. 2, 2017160

${ }^{3}$ Adil Shadiq, Cinta tanpa Nikah Nikah tanpa Cinta, (Solo, Ziyad Visi Media, 2009), 7-8
} 
Berdasarkan hal tersebut, kasih sayang dapat menguatkannya. Begitu juga halnya dengan rumah tangga, ia merupakan insting atau naluri fitri manusia yang dapat mendorong dirinya dengan kuat. Rumah tangga bukanlah sekedar model masyarakat sosial semata. Akan tetapi, rumah tangga merupakan kebutuhan hidup yang mendesak. Hal ini karena kehidupan ini tidak akan berjalan lurus, kecuali melalui jalur pernikahan. Berdasarkan konsep pelitian real melalui kepustakaan ditemukan bahwa koteks antara teori dan dilapangan jauh berbeda tentang pemahaman keluarga sakinah dalam hukum Islam. Dengan demikian keluarga sakinah bukan hanya berfungsi sebagai ikatan biologis, tetapi juga mewujud sebagai tempat berlangusngnya pengajaran dan pendidikan bagi anakanaknya. ${ }^{4}$

Dari pernyataan di atas itu Islam menjadikan keluarga sebagai tempat untuk menjaga diri, yaitu menciptakan ketentraman dan keselamatan dari segala bentuk kejahatan yang ditimbulkan oleh orang lain, sehingga keluarga harus dijadikan tempat tinggal yang penuh dengan kebahagiaan agar seluruh anggota keluarga betah di rumah dan selalu merindui. Sesuai dengan firman Allah dalam surat An-Nahl ayat 80:

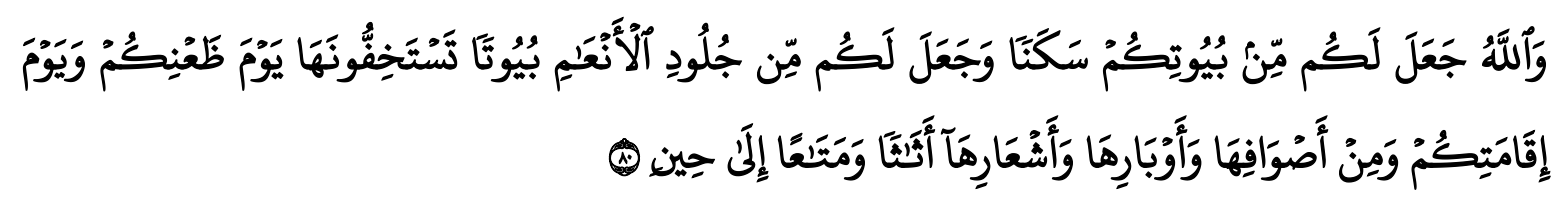

Artinya: Dan Allah menjadikan bagimu rumah-rumahmu sebagai tempat tinggal dan Dia menjadikan bagi kamu rumah-rumah (kemah-kemah) dari kulit binatang ternak yang kamu merasa ringan (membawa)nya di waktu kamu berjalan dan waktu kamu bermukim dan (dijadikan-Nya pula) dari bulu domba, bulu unta dan bulu kambing, alat-alat rumah tangga dan perhiasan (yang kamu pakai) sampai waktu (tertentu).

Untuk mewujudkan keluarga seperti yang di atas, haruslah bersamasama antara suami dan istri untuk mengekalkan cinta yang merupakan anugerah dari Allah, karena tidak dapat dipungkiri bahwa kualitas hubungan suami dan istri dalam rumah tangga sangat mempengaruhi keluarga menjadi sakinah mawaddah wa rahmah. ${ }^{5}$ Keluarga sakinah adalah suatu gambaran keluarga yang harmonis dan ideal, dimana rumah tangganya dihiasi oleh pribadi-pribadi yang soleh secara spiritual dan terpenuhinya kebutuhan pokok yang berupa sandang, pangan dan papan (tempat tinggal). Kehidupan

\footnotetext{
4 Siti Chadijah. (2018). Karakteristik Keluarga Sakinah dalam Islam. Rausyan Fikr: Jurnal Pemikiran dan Pencerahan, 14(1). 115.

5 Sholeh Gisymar, Kado Cinta untuk Istri, (Yogyakarta: Arina, 2005), 91.
} 
suami istri itu adalah rumus dari kebahagiaan dunia. Maka ciptakanlah keluarga yang bahagia agar hidup di dunia juga bahagia. ${ }^{6}$

Dalam keluarga sakinah terdapat, Mahabbah, Mawaddah dan Rahmah QS. (30): 21. Mahabbah adalah cinta yang membara, menggebu-gebu yang hanya melihat kejasmanian lawan jenis saja. Mawaddah adalah jenis cinta yang lebih dititik beratkan kepada kualitas kepribadian lawan jenisnya. Sedang Rahmah adalah jenis cinta yang lembut, siap berkorban dan siap melindungi bagi siapa yang dicintai. Oleh sebab itu didalam keluarga, suami isteri harus sama-sama menjaga dan menghormati ikatan perkawinan yang telah dibuat sebagai sebuah ikatan yang suci.

Penelitian ini menggunakan pendekatan berupa pendekatan Library Research (Kepustakaan). Pendekatan kepustakaan ini adalah merupakan suatu pendekatan yang digunakan dalam mengumpulkan informasi dan data dengan bantuan berbagai macam material yang ada di perpustakaan seperti dokumen, buku, majalah, kisah-kisah sejarah. Dengan menggunakan pendekatan atau jenis kepustakaan penulis ingin menemukan data yang mendukung dalam penelitian ini berupa argumen, kritisisasi, saran dan perbandingan pemahaman penulis lainya tentang permasalahan keluarga sakinah dalam kajian hukum Islam, hal ini juga teknik pengumpulan data dengan melakukan penelaahan terhadap buku, literatur, catatan, serta berbagai laporan yang berkaitan dengan masalah yang ingin dipecahkan Khusu permasalahan yang berkaitan dengan keluarga sakinah dalam hukum Islam

\section{Membina Rumah Tangga dalam Islam}

Pengertian keluarga dalam buku "Menuju Keluarga Sakinah Mawaddah dan Rahmah", Lubis Salim mengatakan bahwa yang dimaksud dengan keluarga adalah kelompok yang terdiri dari ayah, ibu dan anak-anak, sedang sakinah berarti tenang, tentram dan tidak gelisah. Menurut As'ad keluarga sakinah itu ialah adanya ketenangan dan ketentraman hati di dalam hidup keluarga. ${ }^{7}$ Dengan demikian keluarga sakinah adalah sekelompok orang yang terdiri dari ayah, ibu dan anak-anak yang tenang, damai serta saling mencintai dan menyayangi. ${ }^{8}$

Keluarga sakinah akan terwujud jika para anggota keluarga dapat memenuhi kewajiban-kewajibannya terhadap Allah, terhadap diri sendiri, terhadap keluarga, terhadap masyarakat, dan terhadap lingkungannya, sesuai ajaran al-Qur'an dan Sunnah Rasul. ${ }^{9}$ Jadi pada dasarnya keluarga sakinah bisa

\footnotetext{
${ }^{6}$ Abu Mohammad Jibril Abdurrahman, Karakteristik Lelaki Shalih, (Yogyakarta: Wihdah Press, 2000), 21.

${ }^{7}$ Asad, Membangun keluarga sakinah. Tazkiya 7, no. 2 (2018), 3.

${ }^{8}$ Lubis Salam, Menuju Keluarga Sakinah Mawaddah dan Rahmah (Surabaya: Terbit Terang, $\mathrm{t}$, th), 7

${ }^{9}$ Abdul. Kholik, "Konsep Keluarga Sakinah dalam Perspektif Quraish Shihab." Inklusif (Jurnal Pengkajian Penelitian Ekonomi dan Hukum Islam) 2. no. 2 (2017): 22.
} 
dicapai kalau semua anggota keluarga memiliki Mawaddah dan Rahmah, yakni cinta kasih dan kasih sayang.

Ibnu Faris dalam bukunya "Maqayis" yang dikutip oleh M. Quraish Shihab, dikatakan bahwa مودة terambil dari akar kata ود yang berarti cinta dan harapan, selanjutnya al-Baqi' mengatakan bahwa, rangkaian huruf tersebut berarti kelapangan dan kekosongan. Ia adalah kelapangan dada dan kekosongan jiwa dari kehendak buruk. Jika demikian kata ini bermakna cinta tetapi cinta plus cinta yang tampak jauhnya dalam sikap dan perlakuan, serupa dengan kepatuhan sebagaimana hasil masa kagum pada seseorang. Makna ini mirip dengan makna rahmah (رحمة) hanya saja rahmah tertuju kepada yang dihormati, sedang yang dihormati dalam keadaan butuh dan dengan demikian kita dapat berkata bahwa rahmah tertuju kepada yang lemah, sedang mawaddah tidak demikian. ${ }^{10}$

Keluarga Sakinah adalah keluarga yang dibentuk berdasarkan perkawinan yang sah, mampu memberikan kasih sayang kepada anggota keluarganya sehingga mereka memiliki rasa aman, tentram, damai serta bahagia dalam mengusahakan tercapainya kesejahteraan dunia akhirat. Keluarga yang harmonis, sejahtera, tenteram dan damai. Jadi, kata sakinah yang digunakan untuk menyifati kata "keluarga" merupakan tata nilai yang seharusnya menjadi kekuatan penggerak dalam membangun tatanan keluarga yang dapat memberikan kenyamanan dunia sekaligus memberikan jaminan keselamatan akhir. ${ }^{11}$

Sedangkan pengertian rumah tangga, Ali Akbar mengemukakan, rumah tangga adalah suatu organisasi yang mempunyai suatu ikatan bathin. Kuat dan lemahnya rumah tangga tergantung dari manusia-manusia yang membuat ikatan tersebut. Juga tergantung dari macam ikatan yang hendak dibuat. Ikatan yang terkenal dan diakui terkuat adalah cinta. Cinta terhadap suami atau isteri, cinta terhadap isteri dan anak-anak, dan cinta yang timbul antara anak-anak itu sendiri. ${ }^{12}$

Pengalaman dalam kehidupan menunjukkan bahwa membangun keluarga itu mudah, namun memelihara dan membina keluarga hingga mencapai taraf kebahagiaan dan kesejahteraan yang selalu di dambakan oleh setiap pasangan suami isteri alangkah sukarnya. Nilai-nilai agama jugamemiliki peran penting dalam kehidupan keluarga sehingga cara bersikap, menjalankan kewajiban, dan memberikan hak pasangan sesuai dengan ajaran Islam. ${ }^{13}$

Keluarga sakinah yang berintikan ketentraman, kedamaian dan ketenangan hidup merupakan harapan dan tujuan hidup dari sebuah

\footnotetext{
${ }^{10}$ M.Quraish Shihab, Tafsir al-Misbah, Jilid 10 (Cet.III: Jakarta: Lentera Hati, 2005), 477.

11 Siti Chadijah, Karekteristik Keluarga Sakinah dalam Islam. Jurnal Rausyan Fikr. Vol. 14 No.

1 Maret 2018

12 Ali Akbar, Merawat Cinta Kasih (Cet. IX, Jakarta: PT.Pustaka Antara, 1994). 16

13 Muslim Arma, "Keluarga Sakinah Berwawasan Gender." MUWAZAH 9, No.2, (2017),179.
} 
perkawinan. Tidak berlebihan bila dikatakan bahwa keluarga sakinah merupakan prototipe ideal dari bangunan sebuah rumah tangga.

Untuk mewujudkan sebuah keluarga yang sakinah tentu saja memerlukan usaha yang keras, konsisten dan berkesinambungan ${ }^{14}$. Oleh karena itu dalam mencapai sebuah keluarga yang sakinah, mawaddah wa rahmah, perlu memahami terlebih dahulu apa hakekat dan tujuan dari sebuah keluarga, baru kemudian dilanjutkan dengan bagaimana cara membangun sebuah keluarga yang sakinah.

Perkawinan merupakan suatu hal yang lumrah dialami setiap orang. Kiranya bisa disebut sebagai hak pribadi setiap individu yang menginginkan untuk melangsungkannya. Banyak orang yang ingin mencari kebahagiaan melalui perkawinan. Pada hakekatnya, perkawinan adalah rasa cinta kasih, kewajiban pemenuhan hasrat seksual dan pelanjutan keturunan. Bagi Islam rasa cinta kasih adalah rukun pertama sebuah pernikahan, bahkan merupakan motivasinya. Hal tersebut sebagaimana dinyatakan dalam QS. Ar-Ruum (30):21. Sedangkan kewajiban dalam perkawinan adalah kerja sama dalam kedua belah pihak suami isteri dalam mengarungi bahtera rumah kehidupan. Dan inilah yang menjadi rasa cinta kasih berikut perkembangannya sebagaimana rasa cinta kasih itu sendiri menjadi pendorong kuat bagi suami isteri dalam rasa gairah akan senantiasa mewarnai perjalanan suatu perkawinan sampai kapanpun. ${ }^{15}$

Setiap orang dalam melakukan sesuatu tentunya memiliki tujuan. Demikian pula dengan melakukan pernikahan, Didalam Kompilasi Hukum Islam (KHI) Pasal (3) perkawinan bertujuan untuk mewujudkan kehidupan rumah tangga yang sakinah, mawaddah dan rahmah. ${ }^{16}$ Tujuan berkeluarga sangatlah beragam sesuai dengan pelakunya masing-masing. Ada yang bertujuan berkeluarga sebagai jembatan meningkatkan karir, untuk meraih jabatan tertentu, dan lain-lain. Tetapi jika bertolak dari ajaran Islam, maka secara garis besar tujuan berkeluarga itu dapat dikelompokkan menjadi tiga: Pertama, untuk menaati anjuran agama, Kedua, untuk mewujudkan keluarga sakinah, Ketiga, untuk mengembangkan dakwah islamiyah.

Ibrahim Amini menjelaskan ada 3 (tiga) tujuan hidup berkeluarga, pertama, pembentukan sebuah keluarga yang didalamnya seseorang dapat menemukan kedamaian fikiran. Kedua, penyaluran gairah seksual secara benar dan sehat, dan ketiga, reproduksi atau sebagai wadah untuk melangsungkan keturunan. Tetapi tiga tujuan diatas bukan berposisi sebagai tujuan pokok dan tetap harus dibingkai dalam konteks spritual yaitu hidup

\footnotetext{
${ }^{14}$ Hasan Basri, Keluarga Sakinah; Tinjauan Psikologi dan Agama (Yogyakarta: Pustaka Pelajar, 1999), 3.

15 Al-Tahris al-Hadid, Imraatuna fi al-Syari'ah, diterjemahkan oleh M. Adib Bisri dengan judul, Wanita dalam Syar'ah dan Masyarakat (Jakarta: Pustaka Firdaus, 1993), 59.

16 Instruksi Presiden Republik Indonesia Nomor 1 Tahun 1991 Kompilasi Hukum Islam di Indonesia (Jakarta: Direktorat Pembinaan Badan Peradilan Agama, 1998/1999), 1
} 
berkeluarga merupakan suatu alat untuk menghindarkan diri dari perbuatan jelek dan menjauhkan diri dari dosa. ${ }^{17}$

Itulah sebabnya dalam hidup berkeluarga antara suami dan isteri yang akan melahirkan generasinya dan keturunannya yang sah. Tentunya generasinya semenjak lahir bahkan semasa di dalam kandungan itu harus dididik dengan akhlaqul karimah dan kepada mereka ditanamkan aqidah Islamiyah yang kuat, sehingga mereka akan tumbuh dan berkembang menjadi manusia yang kuat iman dan taat terhadap ajaran agamanya.

\section{Kriteria-Kriteria Keluarga Sakinah}

Manusia sebagai makhluk yang berakal diberi kebebasan dan kelengkapan pisik dan psikis serta kecenderungan untuk memilih jalan yang akan ditetapkannya dalam meniti kehidupan, antara jalan kebenaran yang akan mengantarkan pada kebahagiaan hidup hakiki berdasarkan petunjuk Tuhan atau jalan kesesatan yang seakan-akan mengantarkannya kejalan kebahagiaan sehingga kehidupan keluarga yang harmonis terganggu.

Keluarga harmonis adalah suatu keadaan keluarga yang terdapat hubungan komunikasi dengan baik ( $m a^{\prime} r u f$ ) dan saling melindungi. Bila suatu keluarga dikatakan harmonis bila terjadi komunikasi yang baik antara anggota keluarga. Segala persoalan dapat dipecahkan secara internal bersama. ${ }^{18}$ Ternyata melemparkannya kejurang kenistaan, unit keluarga merupakan lingkungan terkecil dan terutama dalam hidup manusia, maka pembinaan pribadi dan lingkungan keluarga yang harmonis adalah tugas dan kewajiban utama dalam menghadapi seluruh problematika kehidupan. Fenomena keluarga yang harmonis dapat terlihat dari kehidupan yang terhindar dari konflik. ${ }^{19}$

Sebagai bentuk keluarga sakinah atau keluarga ideal, maka ada kriteria yang mesti dipenuhi yaitu: pertama, keteguhan niat, kedua, keteguhan pada tujuan pernikahan, ketiga, keteguhan pada pembinaan keluarga, keempat, keteguhan pada pencapaian kualitas dalam pembinaan keluarga dari hasil pernikahan. Pencapaian cita ideal hidup berkeluarga, tidak mungkin tanpa niat yang tulus yang dijelmakan dalam usaha keras untuk meningkatkan kualitas demi kehidupan berkeluarga itu sendiri dalam rangka untuk mencapai cita-cita kebahagiaan hidup sejati. Keluarga yang dimaksud adalah suami istri yang terbentuk melalui suatu perkawinan. Disisni ada titik penekanan melalui perkawinan, kalau tidak melalui perkawinan maka bukan dinamakan keluarga. Maka seorang laki-laki yang hidup bersama dengan

17 Ibrahim Amini, Bimbingan Islam Untuk Kehidupan Suami-Istri (Bandung: al-Bayan, 1996), 17-19.

18 Zainal Arifin, "Tantangan Membentuk Keluarga Sakinah Pada Generasi Milenial." Wahana Islamika: Jurnal Studi Keislaman 6.2 (2020): 203.

${ }^{19}$ R. Zainul Mushthofa dan Siti Aminah. "Tinjauan Hukum Islam Terhadap Praktek Kafa'ah Sebagai Upaya Membentuk Keluarga Sakinah." UMMUL QURA 15.1 (2020): 48. 
seorang perempuan tidak dinamakan keluarga jika keduanya tidak diikat oleh sebuah perkawinan. ${ }^{20}$

Maka dalam membina keluarga sakinah harus benar-benar dipahami, sebab calon isteri dan suami seyogyanya memahami dan manghayati apa pengertian keluarga, bagaimana menurut ajaran Islam, apa tujuannya, serta apa hikmah yang diperoleh setelah melangsungkan pernikahan dan menciptakan keharmonisan antara suami dan isteri.

Setelah menikah pasangan suami isteri akan mengalami kehidupan yang benar-benar baru, berbeda dengan kehidupan sebelum menikah, antara lain: ${ }^{21}$

1. Dituntut untuk memulai hidup mandiri, lepas dari ketergantungan kepada orang tua masing-masing.

2. Suami mulai diminta pertanggungjawaban untuk memenuhi kebutuha lahir dan batin bagi dirinya dan isterinya.

3. Isteri mulai wajib berbakti kepada suami serta membahagiakannya.

4. Suami isteri mulai memikirkan biaya hidup anak-anak mereka agar kelak menjadi lahir anak-anak yang saleh dan salehah.

5. Suami isteri mulai menjadi jembatan untuk mempersaudarakan kedua keluarga besar dari pihak isteri, dan sebaliknya.

6. Suami isteri dituntut untuk dapat hidup bertetangga dan bermasyarakat dengan baik.

Dalam ungkapan lain, konsep keluarga sakinah dalam bentuk praktisnya membutuhkan ketaatan dalam menjalankan ajaran agama Islam, sebab dengan menjalankan ajaran agama sebagaimana mestinya akan menjadi alat kontrol dalam membina keluarga yang dicita-citakan.

Selanjutnya para pakar ilmu berkaitan dengan keluarga telah mengungkapkan beberapa kriteria keluarga sakinah, diantaranya Nurcholish Madjid, menjelaskan makna-makna QS. (30): 21, yang berkaitan dengan kriteria-kriteria keluarga sakinah sebagai berikut: 22

1. Keluarga sakinah harus (wajib) didahului dengan pernikahan sesuai dengan tuntutan ajaran Islam, sehingga persahabatan antara dua orang yang berlainan jenis didahului dengan pernikahan sangat terpuji disisi Allah. Dua orang yang mengadakan ikatan pernikahan (laki-laki dan perempuan) yang tak ternoda sebelumnya, mempunyai makna yang mulia dihadapan Allah swt.

2. Keluarga sakinah bisa dibentuk jika terdapat mahabbah di dalamnya, secara alami seorang tertarik kepada lawan jenisnya, mula-mula karena pertimbangan kejasmanian. Suasana saling tertarik sebab pertimbangan lahiriyah, membuat keduanya jatuh cinta, baik sepihak

\footnotetext{
20 Dwi Runjani Juwita, Konsep Sakinah Mawaddah Warrahmah Menurut Islam. Jurnal AnNuha. Vol 4 Nomor 2, Desember 2017. 205

21 Machfud, Keluarga Sakinah Membina Keluarga Bahagia (Surabaya: Citra Fajar, 2008), 13 14.

${ }^{22}$ Nurcholis Madjid, Masyarakat Religius (Jakarta: Paramadina, 2000), 72-73
} 
(bertepuk sebelah tangan) atau kedua belah pihak (gayung bersambut). Tingkat cinta ini adalah tingkat permulaan yang biasa disebut primitif.

3. Dalam keluarga sakinah ini ada mawaddah, yaitu dua lawan jenis yang jatuh cinta, bukan saja karena pertimbangan kebutuhan biologisnya melainkan yang paling diutamakan adalah pertimbangan kepribadiannya, dan lain sebagainya atau sejenisnya.

4. Keluarga sakinah itu terdapat di dalamnya rahmah yaitu sifat ilahi karena bersumber dari Yang Maha Rahman dan Rahim, yang diberikan kepada setiap hamba-Nya yang dirahmati. Hubungan cinta dua manusia yang berlainan jenis ini dapat mencapai tingkat kualitas yang paling tinggi dan tak terbatas yang serba meliputi; murni dan sejati, hal ini sejalan dengan makna firman Allah swt QS (7): 156 "Rahmatku meliputi sesuatu".

Membina sebuah mahligai rumah tangga atau hidup berkeluarga merupakan perintah agama bagi setiap muslim dan muslimah. Melalui rumah tangga yang islami, diharapkan akan terbentuk komunitas kecil masyarakat Islam. Keluarga adalah satuan terkecil dari masyarakat. Bila setiap keluarga dibina dan dididik dengan baik, sesuai dengan prinsip-prinsip ajaran Islam, maka pada akhirnya akan terbentuk masyarakat yang islami pula. ${ }^{23}$

Islam sangat lekat dengan tatanan rumah tangga. Rumah dalam pandangan Islam merupakan tempat berhimpun dan tempat menetap. Di dalam ayomanya beberapa orang bertemu atas dasar saling mengasihi, saling menyayangi, saling berlemah lembut, menutupi rahasia, bermurah hati, menjaga dan melindungi. Hubungan dalam lingkup rumah tangga ini mencerminkan gambaran yang lembut dan halus, yang dari sana memancar perasaan kasih dan sayang. Allah berfirman al-Qur'an surat Ar-Rum :21:

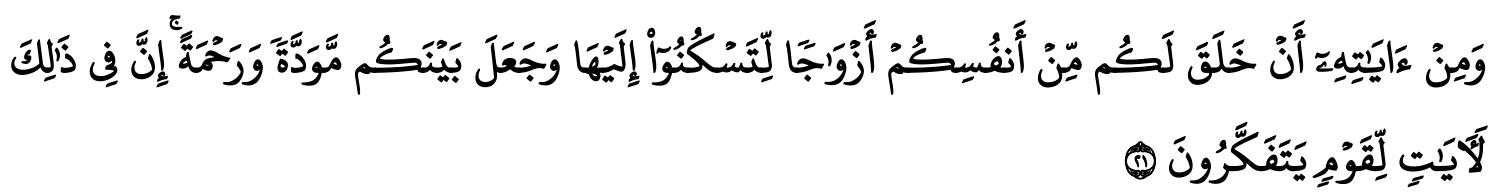

Artinya: Dan di antara tanda-tanda (kekuasaan)-Nya ialah Dia menciptakan pasangan-pasangan untukmu dari jenismu sendiri, agar kamu cenderung dan merasa tenteram kepadanya, dan Dia menjadikan diantara kamu rasa kasih dan sayang. Sungguh pada yang demikian itu benar-benar terdapat tandatanda (kebesaran Allah) bagi kamu yang berfikir". (Q.S. Ar-Rum: 21) ${ }^{24}$

Ayat tersebut menggambarkan jalinan ketentraman, rasa kasih dan rasa sayang sebagai suatu ketenangan yang dibutuhkan oleh masing-masing

${ }^{23}$ Hasbi Indra, dkk, Potret Wanita Shalehah, (Jakarta, Penamadani, 2014), 61

${ }^{24}$ Departemen Agama, RI Al-Qur'an dan Terjemahnya, (Jakarta: Sygma Examedia Arkanleema, 2009), 406. 
individu, laki-laki dan perempuan ketika jauh dari pasangannya. Setiap suami isteri yang menikah, tentu sangat menginginkan kebahagiaan hadir dalam kehidupan rumah tangga mereka, ada ketenangan, ketentraman, kenyamanan dan kasih sayang. Rumah tangga yang menjadi surga dunia tidaklah identik dengan limpahan materi, kebahagiaan bukanlah sebuah kemustahilan untuk dicapai, sebab kebahagiaan merupakan pilihan dan buah dari cara berfikir dan bersikap. Maka dari itu, hanya dengan pasangannyalah ia dapat menikmati manisnya cinta dan indahnya kasih sayang dan kerinduan. ${ }^{25}$

Telah menjadi sunnatullah bahwa setiap orang yang memasuki pintu gerbang rumah tangga melalui pernikahan pasti akan mendambakan sebuah rumah tangga yang bahagia. Rumah tangga bahagia yang dalam bahasa Islam disebut dengan keluarga sakinah, adalah merupakan pilar pembentukan masyarakat ideal yang dapat melahirkan keturunan yang soleh dan di dalamnya ada kehangatan, kasih sayang, kebahagiaan dan ketenangan.

Sebuah rumah tangga yang ideal harus dibangun di atas landasan keagamaan (spiritual), di samping landasan material. Kedua landasan ini pada dasarnya terintegrasi. Karenanya, tidak baik bila hanya didasarkan pada salah satunya saja. Landasan spiritual keagamaan berguna untuk memberi ketenangan, kesejukan, dan kebahagiaan, baik lahir maupun batin, agar tercipta kehidupan keluarga sakinah. Sedangkan landasan materi merupakan sarana yang akan memberikan jaminan bagi kelestarian kehidupan rumah tangga bahagia. Melalui landasan materi, pria bisa memberi mahar dan berbagai macam nafkah untuk memenuhi keperluan keluarga, seperti belanja harian, pakaian, perhiasan, dan penyediaan fasilitas rumah yang memadai.

Keluarga atau rumah tangga yang Islami, dibangun di atas iman dan taqwa sebagai fondasinya, syariah atau aturan Islam sebagai bentuk bangunannya, akhlak dan budi pekerti mulia sebagai hiasannya. Rumah tangga seperti inilah yang akan tetap kokoh dan tidak mudah rapuh dalam menghadapi badai kehidupan dahsyat sekalipun. Rumah tangga adalah wadah yang pertama dalam masyarakat. Masyarakat tidak akan menjadi baik kecuali jika rumah tangga ini baik, dan masyarakat tidak akan rusak kecuali jika rumah tangga ini rusak. Rumah tangga ini terdiri dari rumah, yang namanya rumah harus mencerminkan ketenangan, kedamaian, kerja sama dan rasa cinta. Di sinilah akan akan tumbuh membentuk ciri kebersamaan dan hubungannya. ${ }^{26}$

Meski seseorang gagal karirnya di luar rumah, tetapi sukses membangun keluarga yang kokoh dan sejahtera, maka tetaplah ia dipandang sebagai orang yang sukses dan berbahagia. Sebaliknya orang yang sukses di luar rumah, tetapi keluarganya berantakan, maka ia tidak disebut orang yang beruntung,

${ }^{25}$ A. Chumaidi Umar, Kiprah Muslimah dalam Keluarga Islam (Bandung: Mizan, 2012), 82.

${ }^{26}$ Ummu Ibrahim Ilham Muhammad Ibrahim, Bagaimana Menjadi Istri Shalihah dan Ibu Yang Sukses, (Jakarta: Darul-Falah, 2010), 52. 
karena betapapun sukses diraih, tetapi kegagalan dalam rumah tangganya akan tercermin di wajahnya, tercermin pula pada pola hidupnya yang tidak bahagia hidup menjadi gelisah, tak tenang karena kegagalannya dalam membina rumah tangga. Itulah sebabnya pasangan ideal dari kata keluarga adalah bahagia, sehingga idiomnya menjadi keluarga bahagia. Maknanya, tujuan dari setiap orang yang membina rumah tangga adalah mencari kebahagiaan hidup.

Hampir seluruh budaya bangsa menempatkan kehidupan keluarga sebagai ukuran kebahagiaan yang sebenarnya. Menikah tidak terlalu sulit, tetapi membangun keluarga bahagia bukan sesuatu yang mudah. Pekerjaan membangun, pertama harus didahului dengan adanya gambar yang merupakan konsep dari bangunan yang diinginkan. Gambar bangunan (maket) bisa didiskusikan dan diubah sesuai dengan konsep fikiran yang akan dituangkan dalam wujud bangunan itu. Demikian juga membangun keluarga bahagia, terlebih dahulu orang harus memiliki konsep tentang keluarga bahagia. Ada 5 konsep membangun keluarga bahagia.

1. Dalam keluarga itu ada mawaddah dan rahmah (Q/30:21). Mawaddah adalah jenis cinta membara, yang menggebu-gebu dan "nggemesi", sedangkan rahmah adalah jenis cinta yang lembut, siap berkorban dan siap melindungi kepada yang dicintai. Mawaddah saja kurang menjamin kelangsungan rumah tangga, sebaliknya, Rahmah, lama kelamaan menumbuhkan mawaddah.

2. Hubungan antara suami isteri harus atas dasar saling membutuhkan, seperti pakaian dan yang memakainya. Sebagaimana dalam al-Qur'an surat Al-Baqarah: 187:

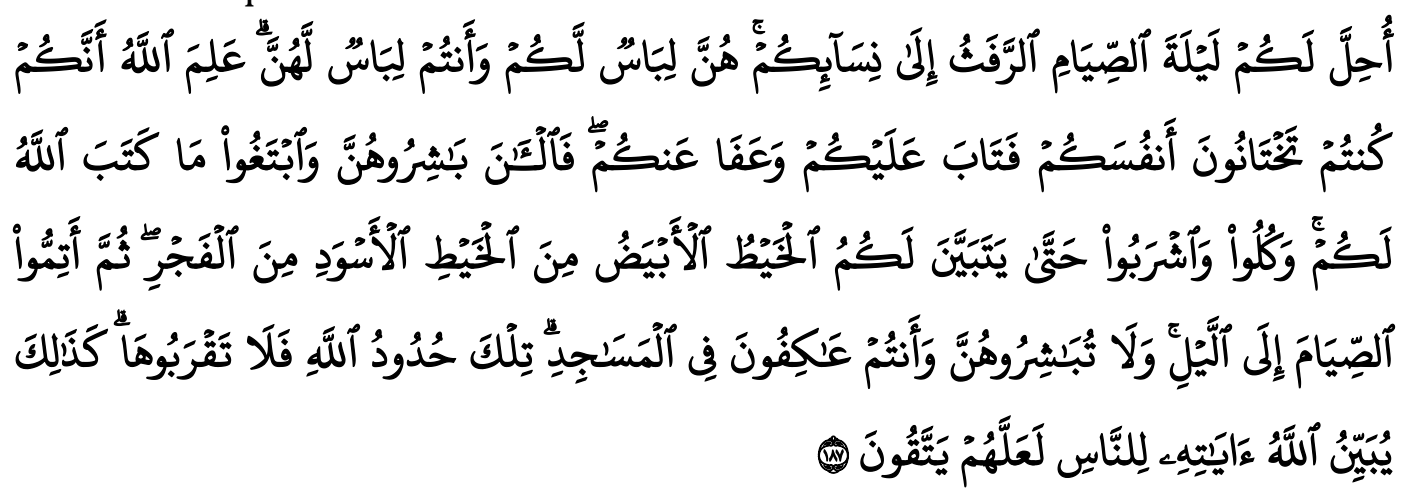

Artinya: Dihalalkan bagi kamu pada malam hari bulan puasa bercampur dengan isteri-isteri kamu; mereka adalah pakaian bagimu, dan kamupun adalah pakaian bagi mereka. Allah mengetahui bahwasanya kamu tidak dapat menahan nafsumu, karena itu Allah mengampuni kamu dan memberi maaf kepadamu. Maka sekarang campurilah mereka dan ikutilah apa yang telah ditetapkan Allah untukmu, dan makan minumlah hingga terang bagimu benang putih dari benang hitam, yaitu fajar. Kemudian sempurnakanlah puasa itu sampai (datang) malam, (tetapi) janganlah kamu campuri mereka itu, 
sedang kamu beri'tikaf dalam mesjid. Itulah larangan Allah, maka janganlah kamu mendekatinya. Demikianlah Allah menerangkan ayatayat-Nya kepada manusia, supaya mereka bertakwa". ${ }^{27}$

Fungsi pakaian ada tiga, yaitu (a) menutup aurat, (b) melindungi diri dari panas dingin, dan (c) perhiasan. Suami terhadap isteri dan sebaliknya harus menfungsikan diri dalam tiga hal tersebut. Jika isteri mempunyai suatu kekurangan, suami tidak menceriterakan kepada orang lain, begitu juga sebaliknya. Jika isteri sakit, suami segera mencari obat atau membawa ke dokter, begitu juga sebaliknya. Isteri harus selalu tampil membanggakan suami, suami juga harus tampil membanggakan isteri, jangan terbalik di luaran tampil menarik orang banyak, di rumah menyebalkan.

3. Suami isteri dalam bergaul memperhatikan hal-hal yang secara sosial dianggap patut (ma'ruf), tidak asal benar dan hak, Wa'a syiruhunna bil ma'ruf (Q/4:19). Besarnya mahar, nafkah, cara bergaul dan sebagainya harus memperhatikan nilai-nilai ma’'ruf. Hal ini terutama harus diperhatikan oleh suami.

4. Suami isteri senantiasa menjaga makanan yang halalan thayyiban. Menurut hadis Nabi, sepotong daging dalam tubuh manusia yang berasal dari makanan haram, cenderung mendorong pada perbuatan yang haram juga.

5. Suami isteri menjaga aqidah yang benar. Akidah yang keliru atau sesat, misalnya mempercayai kekuatan dukun, dan sebangsanya.

Keluarga adalah organisasi sosial dalam format terkecil, namun sangat menentukan kemajuan atau kemunduran suatu masyarakat dalam berbangsa dan bernegara. Salah satu ciri khas keluarga sakinah adalah menjadi suri teladan atau pembina masyarakat muslim. Alangkah indahnya jika keluarga tersebut di samping sebagai suri teladan masyarakat muslim, juga sebagai keluarga yang senantiasa mengajak kepada kebaikan dan mencegah keburukan. ${ }^{28}$

\section{Implementasi Keluarga Sakinah}

Mempunyai keluarga yang sakinah menjadi idaman setiap orang. Kenyataan menunjukkan banyak orang yang merindukan rumah tangga menjadi sesuatu yang teramat indah, penuh bahagia, penuh dengan berkah. Kenyataan pun membuktikan tidak sedikit keluarga yang hari demi harinya hanyalah berpindah dari kecemasan kegelisahan, dan penderitaan. Bahkan tidak jarang diakhiri dengan kenistaan, perceraian, dan juga derita. Ternyata merindukan keluarga yang sakinah mawaddah wa rahmah itu tidak asal jadi,

\footnotetext{
27Departemen Agama, RI Al-Qur'an dan Terjemahnya, (Jakarta: Sygma Examedia Arkanleema, 2009), 28.

${ }^{28}$ Slamet Abidin, et.all, Fiqh Munakahat, (Bandung: Pustaka Setia, 2009), 12-18.
} 
yang hanya berbekal cinta dan harapan, tapi butuh kesungguhan. Mengerahkan segala kemampuan kemampuan untuk mewujudkannya. Butuh kerja keras dan kemauan yang kuat. 29

Ada beberapa indikasi yang bisa mengantarkan keluarga menjadi keluarga yang bahagia, Pertama, dengan menjadikan keluarga yang ahli sujud, keluarga yang ahli taat, keluarga yang menghiasi diringan dengan dzikrullah, dan keluarga yang selalu rindu untuk mengutuhkan kemuliaan hidup di dunia, terutama mengutuhkan kemuliaan di hadapan Allah swt kelak di surga. Kedua, menjadikan rumah sebagai pusat ilmu. Pupuk iman adalah pusat ilmu. Memiliki harta tetapi kurang ilmu akan menjadikan kita diperbudaknya. Harta dinafkahkan akan habis, ilmu dinafkahkan akan melimpah. Jadikan agar keluarga sungguh-sungguh untuk mencari ilmu, baik ilmu tentang hidup di dunia maupun di akhirat. Bekali anak-anak sejak kecil dengan ilmu dan jadilah orang tua yang senantiasa menjadi sumber ilmu bagi anak-anaknya.

Ketiga, jadikan rumah tangga sebagai pusat nasehat. Semakin hari banyak yang harus dilakukan. Untuk itu manusia membutuhkan orang lain agar bisa melengkapi kekurangan guna memperbaiki kesalahan yang ada. Keluarga yang bahagia itu keluarga yang dengan sadar menjadikan kekayaannya saling menasehati, saling memperbaiki, serta saling mengoreksi dalam kebenaran dan kesabaran. Setiap koreksian bahkan pujian yang diberikan pada keluarga patut di syukuri. Apabila sebuah keluarga saling menasihati, maka keluarga bagaikan cermin yang akan membuat anggota keluarganya berpenampilan lebih baik, karena tidak pernah ada koreksi yang paling aman selain koreksi dari keluarga.

Keempat, jadikan rumah sebagai pusat kemuliaan. Pastikan keluarga sebagai contoh bagi keluarga yang lain. Berbahagialah jika keluarga dijadikan contoh teladan bagi keluarga yang lain.

Perkawinan yang baik adalah sebuah ikatan seumur hidup dan memerlukan sesuatu yang lebih banyak daripada sekedar "peduli", "pemenuhan diri", dan "komitmen". Perkawinan menuntut agar masingmasing kita jujur kepada diri sendiri, jujur kepada pasangan hidup dan jujur kepada Allah. Islam memandang potret keluarga yang ideal adalah keluarga yang dapat menggabungkan antara sakinah, mawaddah dan rahmah sebagai satu kesatuan dan dapat merealisasikannya dalam kehidupan sehari-hari. Untuk dapat mencapainya, tentu membutuhkan cara dan langkah yang beragam, bisa saja berbeda antara satu keluarga dengan lainnya. Uraian berikut ini memberikan semacam tips atau upaya-upaya bagi pembentukan sebuah keluarga bahagia yang sifatnya umum namun bisa direalisasikan dalam setiap keluarga;

${ }^{29}$ BP4, Perkawinan \& Keluarga, dalam Membangun Keluarga Sakinah, majalah bulanan. No. 451/XXXVIII/2010, Diterbitkan Badan Penasehatan, Pembinaan dan Pelestarian Perkawinan (BP4) Pusat. 2010, 16. 
Pertama, Perkawinan merupakan sebuah ikatan yang bertujuan untuk menjaga kelangsungan kehidupan kemanusiaan. Oleh karena itu secara naluriah manusia akan berusaha untuk mendapatkan pasangan hidup yang sesuai dengan keinginan mereka walaupun dalam ketentuan agama dianjurkan untuk selektif dalam memilih pasangan. Permasalahan memilih jodoh merupakan sesuatu yang pernah dialami oleh orang dalam menempuh rumah tangga. Seseorang dalam memilih calon istri atau suami mesti dipertimbangi oleh kriteria tertentu, walaupun upaya tersebut bukan merupakan suatu yang kunci, namun dapat menentukan baik tidaknya rumah tangga. ${ }^{30}$

Kedua, Segala aspek kehidupan dalam rumah tangga harus diputuskan dan diselesaikan berdasarkan hasil musyawarah minimal antara suami dan istri. Adapun maksud demokratis adalah bahwa seluruh anggota keluarga harus saling terbuka untuk menerima pandangan dari masing-masing pihak. Untuk merealisasikan prinsip ini, maka setiap anggota keluarga harus saling menciptakan suasana yang kondusif untuk munculnya rasa persahabatan di antara mereka baik dalam hal suka maupun duka, dan merasa mempunyai kedudukan yang sejajar dan bermitra, tidak ada pihak yang merasa lebih hebat dan lebih tinggi kedudukannya, tidak ada pihak yang mendominasi dan menguasai. Dengan prinsip ini diharapkan akan memunculkan kondisi yang saling melengkapi dan saling mengisi antara satu dengan yang lain. ${ }^{31}$

Realisasi lebih jauh dari sikap musyawarah dan demokratis dapat dikelompokkan kepada: pertama, musyawarah dalam memutuskan masalahmasalah yang berhubungan dengan reproduksi, jumlah dan pendidikan anak dan keturunan, kedua, musyawarah dalam menentukan tempat tinggal (rumah), ketiga, musyawarah dalam memutuskan masalah-masalah yang dihadapi dalam kehidupan rumah tangga, dan keempat, musyawarah dalam pembagian tugas-tugas rumah tangga ${ }^{32}$

Ketiga, Dalam kehidupan rumah tangga harus tercipta suasana yang merasa saling kasih, saling asih, saling cinta, saling melindungi dan saling sayang. Semua anggota keluarga harus menciptakan suasana bahwa rumah adalah tempat yang nyaman bagi mereka. Keluarga menurut Toffler, dapat berfungsi laksana raksasa peredam kejutan yakni tempat kembali berteduh setiap individu (anggota keluarga) yang babak belur dan kalah dalam pertaruhan hidup diluar rumah. ${ }^{33}$ Dalam bahasa Islam, keluarga berfungsi sebagai surga atau taman indah, tempat setiap anggota keluarga menikmati

\footnotetext{
30 M. Alfatih Suryadilaga (ed.), Membina Keluarga Mawaddah Wa Rahmah dalam Bingkai Sunah Nabi (Yogyakarta: PSW IAIN Sunan Kalijaga, 2003), 107.

31 Khoiruddin Nasution, Islam Tentang Relasi Suami dan Istri (Hukum Perkawinan 1) (Yogyakarta: ACADEMIA+TAZZAFA, 2004), 36.

32 Khoiruddin Nasution, Islam Tentang Relasi, 36.

${ }^{33}$ Alvin Toffler, Kejutan dan Gelombang, terj. Sri Kasdiyantinah (Jakarta: Pantja Simpati, 2007), 239.
} 
kebahagiaan hidup, dan menjadi penangkal gelombang kehidupan yang keras. Jika suasana kehidupan keluarga berantakan dan terpecah, tidak aman dan tentram maka kehidupan keluarga akan mengalami dis-orientasi, dis-harmoni, bahkan disintegrasi. Aman dan tentram disini bukan hanya terbatas pada aspek fisik semata, tetapi juga dalam aspek kehidupan kejiwaan (psikis). ${ }^{34}$

Keempat, Dalam kehidupan berkeluarga, jangan sampai ada anggota keluarga yang merasa berhak memukul atau melakukan tindak kekerasan fisik dalam bentuk apapun, dengan dalih atau alasan apapun, termasuk alasan atau dalih agama. Begitu juga setiap anggota keluarga harus terhindar dari kekerasan psikologi. Setiap anggota keluarga harus mampu menciptakan suasana kejiwaan yang aman, merdeka, tentram dan bebas dari segala bentuk ancaman yang bersifat kejiwaan, baik dalam bentuk kata atau kalimat seharihari yang digunakan maupun panggilan antar anggota keluarga yang menimbulkan rasa tidak aman dan ketakutan bahkan sekedar ketersinggungan.

Kelima, Relasi gender dalam hubungan suami dan isteri dan anggota keluarga lainnya merupakan hubungan kemitrasejajaran. Meskipun pengertian kemitrasejajaran tidak bisa difahami dengan makna yang seragam, persis sama, tetapi pengertian kemitrasejajaran yang dimaksud disini adalah suatu relasi yang berdasarkan keadilan, saling membutuhkan, dan saling melengkapi antara satu dengan yang lainnya. ${ }^{35}$ Implikasi dari prinsip seperti ini akan memunculkan sikap, pertama saling mengerti latar belakang pribadi, kedua, saling menerima hobi, kelebihan dan kekurangan dari masing-masing anggota keluarga, ketiga, saling menghormati perkataan, perasaan, bakat dan keinginan serta menghargai keluarga, keempat, saling mempercayai pribadi maupun kemampuan setiap anggota keluarga, kelima, saling mencintai dan menjauhi sikap egois.

Keenam, Keadilan disini adalah menempatkan sesuatu pada posisi yang semestinya (proporsional). Jika ada diantara anggota keluarga baik laki-laki maupun perempuan yang mendapatkan kesempatan untuk mengembangkan diri harus di dukung tanpa memandang dan membedakan berdasarkan jenis kelamin. Masing-masing anggota keluarga harus sadar sepenuhnya bahwa dirinya adalah bagian dari keluarga yang harus memberi dan mendapat perhatian. Contohnya, bapak yang kerja dan mempunyai kewajiban di kantor atau sekolah, juga mempunyai kewajiban untuk memberikan perhatian kepada anak-anak, isterinya serta anggota keluarga lainnya.

Demikian pula, ibu yang harus menuntaskan tugas kantor, tugas sekolah juga mempunyai kewajiban untuk memberikan perhatian bagi suami, anakanak, dan anggota keluarga lainnya. Ini berarti semua anggota keluarga harus

34 Khoiruddin Nasution, Islam Tentang Relasi Suami dan Istri (Hukum Perkawinan 1), 58-59

35 Hamim Ilyas, "Jender dalam Islam: Masalah Penafsiran", dalam Jurnal Asy-Syir'ah 35, No. II (2010), 29. 
berlaku adil baik bagi dirinya dan anggota keluarganya. Suami, isteri dan anggota keluarga adalah team-work dan team-meat dalam mencapai keluarga yang bahagia. Segala sesuatu menyangkut tugas-tugas untuk menciptakan keluarga yang sakinah haruslah adil, fleksibel, terbuka dan demokratis. Intinya berbagi tugas sesuai dengan kondisi objektif, atas kesepakatan bersama, dan untuk mencapai tujuan bersama. ${ }^{36}$

Ketujuh, Kebahagiaan dan kesejahteraan dalam perkawinan mempunyai beberapa unsur, baik yang seharusnya dipunyai seorang pria yang nantinya akan berfungsi sebagai suami ataupun seorang wanita yang akan menjadi seorang isteri dan ibu dari anak-anaknya. Sebagian orang beranggapan bahwa unsur terpenting dalam membangun keluarga adalah masing-masing pasangan saling mencintai. Ada juga yang menyatakan bahwa kekayaan dan kecantikan menjadi modal bagi kebahagiaan sebuah keluarga. Salah satu unsur terpenting dalam mencapai kebahagiaan dalam rumah tangga adalah kedewasaan diri. Kedewasaan dalam bidang fisik-biologis, sosial ekonomi, emosi dan tanggung jawab, pemikiran dan nilai-nilai kehidupan serta keyakinan atau agama, akan menyebabkan keluarga yang terbentuk dalam keadaan yang demikian mempunyai saham yang cukup besar dan meyakinkan untuk meraih taraf kebahagiaan dan kesejahteraan hidup dalam keluarganya. ${ }^{37}$

\section{Penutup}

Keluarga Sakinah adalah keluarga yang dibentuk berdasarkan perkawinan yang sah, mampu memberikan kasih sayang kepada anggota keluarganya sehingga mereka memiliki rasa aman, tentram, damai serta bahagia dalam mengusahakan tercapainya kesejahteraan dunia akhirat. Keluarga yang harmonis, sejahtera, tenteram dan damai. Tujuan berkeluarga itu dapat dikelompokkan menjadi tiga: Pertama, untuk menaati anjuran agama, Kedua, untuk mewujudkan keluarga sakinah, Ketiga, untuk mengembangkan dakwah islamiyah. Kriteria keluarga sakinah diantaranya: pertama, keteguhan niat, kedua, keteguhan pada tujuan pernikahan, ketiga, keteguhan pada pembinaan keluarga, keempat, keteguhan pada pencapaian kualitas dalam pembinaan keluarga dari hasil pernikahan. Ada beberapa upaya membina keluarga sakinah, Pertama, dengan menjadikan keluarga yang ahli sujud, keluarga yang ahli taat, terutama mengutuhkan kemuliaan di hadapan Allah swt. Kedua, menjadikan rumah sebagai pusat ilmu. Ketiga, menjadikan rumah tangga sebagai pusat nasehat. Keempat, menjadikan rumah sebagai pusat kemuliaan.

${ }^{36}$ Dudung S. Ansori, Memperbincangkan Feminisme (Bandung: Pustaka Hidayah, 1996), 219223

${ }^{37}$ Hasan Basri, Keluarga Sakinah; Tinjauan Psikologi dan Agama (Yogyakarta: Pustaka Pelajar, 2009), 6-7 


\section{Daftar Pustaka}

Abdurrahman Jibril Mohammad Abu. Karakteristik Lelaki Shalih. Yogyakarta: Wihdah Press, 2000.

Abidin Slamet, et.all. Fiqh Munakahat. Bandung: Pustaka Setia, 2009.

Akbar Ali. Merawat Cinta Kasih. Jakarta: PT.Pustaka Antara, 1994.

Al-Hadid Al-Tahris. Imraatuna fi al-Syari'ah, diterjemahkan oleh M. Adib Bisri dengan judul, Wanita dalam Syar'ah dan Masyarakat. Jakarta: Pustaka Firdaus, 1993.

Al-Masayyar M. Sayyid Ahmad. Fiqih Cinta Kasih, Rahasia Kebahagiaan Rumah Tangga. Jakarta, Airlangga, 2008.

Amini Ibrahim. Bimbingan Islam Untuk Kehidupan Suami-Istri. Bandung: alBayan, 1996.

Ansori Dudung S. Memperbincangkan Feminisme. Bandung: Pustaka Hidayah, 1996.

Arifin, Zainal. "Tantangan Membentuk Keluarga Sakinah Pada Generasi Milenial." Wahana Islamika: Jurnal Studi Keislaman 6.2. 2020.

Arma, Muslim. "Keluarga Sakinah Berwawasan Gender." MUWAZAH Vol. 9, No.2, 2017.

Asad, "MEMBANGUN KELUARGA SAKINAH." TAZKIYA 7.2, 2018.

Basri Hasan. Keluarga Sakinah; Tinjauan Psikologi dan Agama (Yogyakarta: Pustaka Pelajar, 2009)

BP4. Perkawinan \& Keluarga, dalam Membangun Keluarga Sakinah, majalah bulanan. No. 451/XXXVIII/2010, Diterbitkan Badan Penasehatan, Pembinaan dan Pelestarian Perkawinan (BP4) Pusat. 2010, 16.

Chadijah Siti. Karekteristik Keluarga Sakinah dalam Islam. Jurnal Rausyan Fikr. Vol. 14 No. 1 Maret 2018

Departemen Agama. RI Al-Qur'an dan Terjemahnya. Jakarta: Sygma Examedia Arkanleema, 2009.

Gisymar Sholeh. Kado Cinta untuk Istri. Yogyakarta: Arina, 2005.

Ilyas Hamim, "Jender dalam Islam: Masalah Penafsiran", dalam Jurnal AsySyir'ah, Vol.35, No. II, 2010.

Indra Hasbi, dik. Potret Wanita Shalehah. Jakarta, Penamadani, 2014.

Instruksi Presiden Republik Indonesia Nomor 1 Tahun 1991 Kompilasi Hukum Islam di Indonesia. Jakarta: Direktorat Pembinaan Badan Peradilan Agama, 1998/1999.

Juwita Dwi Runjani. Konsep Sakinah Mawaddah Warrahmah Menurut Islam. Jurnal An-Nuha. Vol 4 Nomor 2, 2017.

Kholik, Abdul. "KONSEP KELUARGA SAKINAH DALAM PERSPEKTIF QURAISH SHIHAB." INKLUSIF (JURNAL PENGKAJIAN PENELITIAN EKONOMI DAN HUKUM ISLAM) 2. 2, 2017.

Machfud. Keluarga Sakinah Membina Keluarga Bahagia. Surabaya: Citra Fajar, 2008.

Madjid Nurcholis. Masyarakat Religius. Jakarta: Paramadina, 2000.

Mawarid Amirah. Pendidikan Pra Nikah ; Ikhtiar Membentuk Keluarga Sakinah. Jurnal Tarbawi. Volume 2. No. 2, 2017. 
Muhammad Ibrahim Ummu Ibrahim Ilham. Bagaimana Menjadi Istri Shalihah dan Ibu Yang Sukses. Jakarta: Darul-Falah, 2010.

Mushthofa, R. Zainul, and Siti Aminah. "TINJAUAN HUKUM ISLAM TERHADAP PRAKTEK KAFA'AH SEBAGAI UPAYA MEMBENTUK KELUARGA SAKINAH." UMMUL QURA 15. 1. 2020.

Nasution Khoiruddin. Islam Tentang Relasi Suami dan Istri. Hukum Perkawinan 1, Yogyakarta: ACADEMIA+TAZZAFA, 2004.

Salam Lubis. Menuju Keluarga Sakinah Mawaddah dan Rahmah. Surabaya: Terbit Terang, t,Th.

Shadiq Adil. Cinta tanpa Nikah Nikah tanpa Cinta. Jakarta: Ziyad Visi Media, 2009.

Shihab M.Quraish. Tafsir al-Misbah, Jilid 10. Jakarta: Lentera Hati, 2005.

Suryadilaga M. Alfatih (ed.). Membina Keluarga Mawaddah Wa Rahmah dalam Bingkai Sunah Nabi. Yogyakarta: PSW IAIN Sunan Kalijaga, 2003.

Toffler Alvin. Kejutan dan Gelombang, terj. Sri Kasdiyantinah. Jakarta: Pantja Simpati, 2007.

Umar Chumaidi. Kiprah Muslimah dalam Keluarga Islam. Bandung: Mizan, 2012. 